\title{
LOKKAITE, A NEW HYDROUS RE-CARBONATE FROM PYÖRÖNMAA PEGMATITE IN KANGASALA, SW-FINLAND
}

\author{
Vesa Pertitunen
}

\begin{abstract}
Perttunen, Vesa 1971: Lokkaite, a new hydrous RE-carbonate from Pyörönmaa pegmatite in Kangasala, SW-Finland. Bull. Geol. Soc. Finland 43, $67-72$.
\end{abstract}

Lokkaite is a new RE-carbonate found in an old pegmatite quarry as a supergene mineral associated with tengerite. Electron microprobe analysis gave: $\mathrm{Y}$-earths $48.7 \%$, Ce-earths $4.3 \%, \mathrm{CaO} 3.2 \%$ and $\mathrm{Fe}_{2} \mathrm{O}_{3} 0.4 \%$. Thermal decomposition gave: $\mathrm{CO}_{2} 32.4 \%, \mathrm{H}_{2} \mathrm{O}+1.6 \%$ and $\mathrm{H}_{2} \mathrm{O}-5.4 \%$, total $96.0 \%$. When omitting $\mathrm{Fe}$ the analysis gives the formula $\mathrm{Ca}_{\mathbf{0 . 2 3}} \mathrm{RE}_{\mathbf{1 . 5 8}}\left(\mathrm{CO}_{2.87}\right)_{3}{ }^{\circ}$ $1.58 \mathrm{H}_{2} \mathrm{O}$.

Lokkaite is orthorhombic, the diffraction symbol is $m m m B--; a_{0}=39.07$ $\AA, b_{0}=6.079 \AA$ and $c_{0}=9.19 \AA$. The mineral has a distinct superstructure. The dimensions of the sub-cell are: $a_{0}^{\prime}=1 / 2 a_{0}, b_{0}^{\prime}=b_{0}$ and $c_{0}^{\prime}=1 / 2 c_{0}$, and the diffraction symbol is $m \mathrm{mmPb}$-.. The strongest $\mathrm{X}$-ray powder lines of lokkaite are: 19.59 (35), 9.77 (50), 6.509 (55), 5.792 (45), 4.594 (75), 3.902 (60), 3.808 (100), 2.931 (40), 2.535 (35) and 2.045 (35).

The colour is white, $\alpha=1.569, \beta=1.592$ and $\gamma=1.620$. Elongation is positive and $c / / Z$.

The name lokkaite is in honour of the late Professor Lauri Lokka, former Chief Chemist of the Geological Survey of Finland, in recognition of his valuable contributions to the chemistry and mineralogy of the RE-pegmatites of Finland. The name was approved in advance of publication by the Commission on New Minerals and Mineral Names of the IMA.

Vesa Perttunen, Geological Survey of Finland, Otaniemi, Finland.

\section{Introduction}

The supergene carbonate mineralization of the Pyörönmaa pegmatite was detected during the study on the RE-minerals of the pegmatite published by Vorma et al. (1966). In that paper the chemical analysis and the $\mathrm{X}$-ray powder pattern of a hydrous RE-carbonate were given. The mineral was provisionally named tengerite. Later one of the cited authors (A. Vorma) was informed by Dr. Akira Kato of the X-ray powder data of tengerite from Iisaka, Japan. Dr. Kato also suggested that the carbonate mineral of Pyörönmaa is not tengerite. At that point the present author received the material of the Pyörönmaa pegmatite for further study.

\section{Occurrence}

The main minerals in the Pyörönmaa pegmatite are potash feldspar, albite and quartz; 


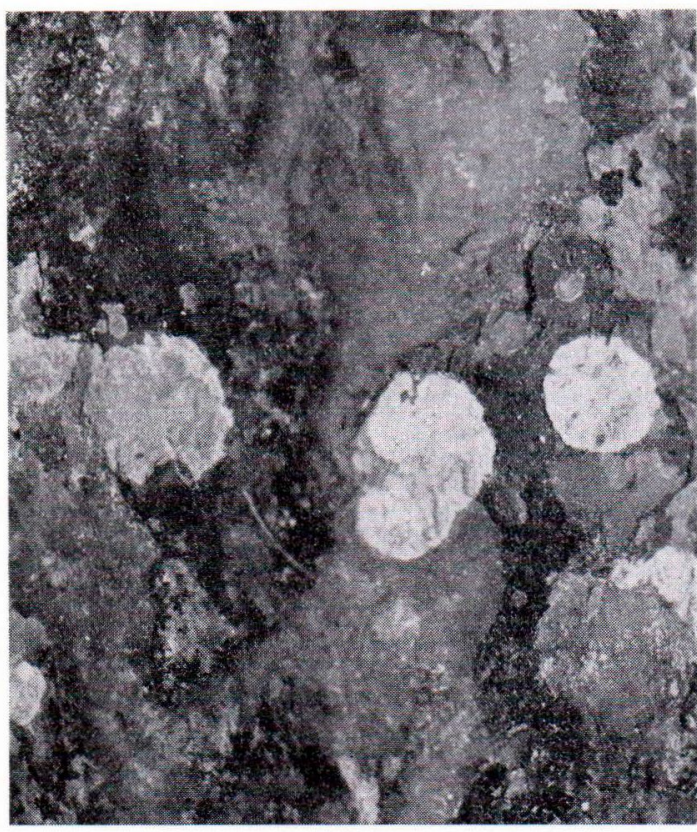

Fig. 1. Lokkaite incrustations as white radial aggregates on albite. Pyörönmaa, Kangasala. Magn. 8.5 x. Photo: Erkki Halme (in Vorma et al. 1966, Fig. 13).

biotite and garnet occur as minor constituents. The pegmatite is known for its many RE-minerals, such as allanite, gadolinite, britholite, thalenite, fergusonite, bastnäsite and synchysite (Vorma et al., 1966).

The supergene alteration of the primary minerals of the pegmatite has created new carbonate minerals. The mineral provisionally named tengerite proved to be a new species. It occurs as isolated white radial disc-like aggregates $0.5-1.0 \mathrm{~mm}$ in diameter on the surfaces and in the fissures of albite (Fig. 1). In addition to spheroids the mineral occurs as white powdery incrustations intimately associated with tengerite.

The aim of this paper is to give a mineralogical description of the new mineral which is named lokkaite in honour of the late Professor Lauri Lokka, former Chief Chemist of the Geological Survey of Finland. The name lokkaite was
TABLE 1

The chemical composition of lokkaite from Pyörönmaa.

1 - 2

$\mathrm{CaO} \ldots \ldots \ldots \ldots \ldots \ldots \ldots \ldots$

$2.6-3.4$

3.2

$\mathrm{Fe}_{2} \mathrm{O}_{3} \quad \ldots \ldots \ldots \ldots \ldots \ldots \ldots$

$\mathrm{Y}_{2} \mathrm{O}_{3} \ldots \ldots \ldots \ldots \ldots \ldots$

$\mathrm{La}_{2} \mathrm{O}_{3} \ldots \ldots \ldots \ldots \ldots \ldots$

$\mathrm{Ce}_{2} \mathrm{O}_{3} \ldots \ldots \ldots \ldots \ldots \ldots \ldots$

$\mathrm{Pr}_{2} \mathrm{O}_{3} \ldots \ldots \ldots \ldots \ldots \ldots$

$0.3-0.4$

$29-29.5$

$0.2-0.3$

$0.6-1.1$

$0.2-0.4$

$1.1-1.8$

$1.6-2.2$

$\mathrm{Sm}_{2} \mathrm{O}_{3}$

$\begin{array}{lll}\mathrm{Gd}_{2} \mathrm{O}_{3} \ldots \ldots \ldots \ldots \ldots \ldots \ldots & 4.1-5.4 \\ \mathrm{~Tb}_{2} \mathrm{O}_{3} \ldots \ldots \ldots \ldots \ldots & 1.1-1.5\end{array}$

$\mathrm{Dy}_{2} \mathrm{O}_{3} \ldots \ldots \ldots \ldots \ldots \ldots \ldots .6 .2-8.8$

$\mathrm{Ho}_{2} \mathrm{O}_{3} \ldots \ldots \ldots \ldots \ldots \ldots$

$\mathrm{Er}_{2} \mathrm{O}_{3} \ldots \ldots \ldots \ldots \ldots \ldots$

$\mathrm{Tm}_{2} \mathrm{O}_{3} \ldots \ldots \ldots \ldots \ldots \ldots$

$\mathrm{Yb}_{2} \mathrm{O}_{3} \ldots \ldots \ldots \ldots \ldots \ldots$

$\mathrm{Lu}_{2} \mathrm{O}_{3} \ldots \ldots \ldots \ldots \ldots \ldots$

$\mathrm{CO}_{2} \ldots \ldots \ldots \ldots \ldots \ldots \ldots$

$\mathrm{H}_{2} \mathrm{O}-\ldots \ldots \ldots \ldots \ldots \ldots$

$\mathrm{H}_{2} \mathrm{O}+\ldots \ldots \ldots \ldots \ldots$

$3.1-4.4$

$0.7-1.2$

$1.8-3.0$

0.4

29.0

0.2

0.7

0.3

1.3

1.8

4.6

1.2

6.8

trace

4.0

0.9

2.2

trace

32.4

5.4

$\frac{1.6}{96.0}$

1. Oxide

2. Range of results in per cents

3. Mean value published in Vorma et al., 1966

Number of microprobe analyses: $\mathrm{Ca}-\mathrm{Y}=3$; $\mathrm{La}-\mathrm{Lu}$ $=6$.

F, Be, Al, Pb, Ti, Mn, Mg, Eu and Si were not detected. $\mathrm{Be}$ by optical spectrograph, F by titration, others by microprobe.

approved by the Commission on New Minerals and Mineral Names of the IMA.

\section{Chemistry}

The chemical analysis of lokkaite (Table 1) was published by Vorma et al. (1966). Cations were analyzed by an electron microprobe analyzer model »Geoscan» (Be by optical spectrograph). $\mathrm{CO}_{2}, \mathrm{H}_{2} \mathrm{O}$ and $\mathrm{F}$ were determined by conventional procedures. The amount of pure material available was too small for wet chemical analysis. The samples, total $7.2 \mathrm{mg}$, from which $\mathrm{CO}_{2}$ and $\mathrm{H}_{2} \mathrm{O}$ were determined were slightly contaminated by tengerite. The analysis suggests the chemical formula $\mathrm{Ca}_{0,23} \mathrm{RE}_{1,58}\left(\mathrm{CO}_{2,87}\right)_{3} \cdot 1.58 \mathrm{H}_{2} \mathrm{O}$ for lokkaite.

\section{X-ray crystallography}

Lokkaite was investigated by $\mathrm{X}$-ray powder and single-crystal methods. The crystals are 
fibrous and even the smallest fibres used in the single-crystal study were actually crystal bundles. The $c$-axis of each individual crystal is parallel to the fibre. The reflections on the Weissenberg photographs appear as $1-2 \mathrm{~mm}$ long lines.

The approximate unit cell dimensions were measured from the $c$-axis oscillation and zerolevel Weissenberg photographs. More precise dimensions were calculated from the indexed X-ray powder diffraction pattern (Table 2) calibrated by quartz. The unit cell dimensions of lokkaite are:

$$
\begin{aligned}
& a_{0}=39.07 \AA \\
& b_{0}=6.079 \AA \\
& c_{0}=9.19 \AA
\end{aligned}
$$

The intensities of the reflections were measured from the heights of the peaks on the chart. The sample for $\mathrm{X}$-ray spectrometer runs was contaminated by tengerite and albite. The presence of tengerite as an impurity enhances the intensity of reflections $4.596 \AA(002)$ and $2.535 \AA$ (022) of lokkaite and thus the actual intensity of these reflections is smaller than given in Table 2 . In any case, the 022 -reflection is present on the $c$-axis second-level Weissenberg photograph and the presence of the 002reflection was checked by the precession method.

According to the $c$-axis oscillation and 0 -, 1st-, 2nd-, 3rd- and 4th-level Weissenberg photographs the Laue-class of lokkaite is $\mathrm{mmm}$. Only the reflections with $b+l=2 n$ exist, so the possible space groups are: $B 222$ (21), $B m 2 m$ (35), Bmmm (65) and B2mm (38). The figures in parentheses correspond to the space group numbers in »International tables for X-ray crystallography» (1952). Lokkaite has a distinct superstructure. The dimensions of the sub-cell are: $a_{0}^{\prime}=1 / 2 a_{0}, \quad b_{0}^{\prime}=b_{0}$ and $c_{0}^{\prime}=1 / 2 c_{0}$ and the possible space groups $P b 2 m$ (26), Pbm2 (28) and Pbmm (51).

\section{Physical properties}

The crystals of lokkaite in the radial aggregates are straight, brittle fibres. The grain size in the powdery incrustations of lokkaite and tengerite is less than $0.01 \mathrm{~mm}$ and individual crystals cannot be distinguished. The colour is white, sometimes stained to yellow.

The indices of refraction of lokkaite are $(\mathrm{Na}$, $\left.22^{\circ} \mathrm{C}\right): \alpha=1.569, \beta=1.592$ and $\gamma=1.620$. The crystals are too small for $2 \mathrm{~V}$ measurements by Universal stage. The elongation is positive and $c / / Z$.

\begin{tabular}{|c|c|c|c|c|}
\hline$b k l$ & $d(\AA)$ & $I_{o b s}$ & $\sin ^{2} \Theta_{o b s}$ & $\sin ^{2} \Theta_{c a l c}$ \\
\hline 200 & 19.59 & 35 & 0.00155 & 0.00156 \\
\hline 400 & 9.77 & 50 & .00623 & .00623 \\
\hline $600^{*}$ & 6.509 & 55 & .01403 & .01402 \\
\hline 210 * & 5.792 & 45 & .01771 & .01764 \\
\hline 410 & 5.17 & 5 & .02223 & .02232 \\
\hline $002^{*}$ & 4.594 & $\left.75^{1}\right)$ & .02816 & .02815 \\
\hline 610 & 4.43 & 10 & .03027 & .03010 \\
\hline $1000^{*}$ & 3.902 & 60 & .03903 & .03893 \\
\hline $810 *$ & 3.808 & 100 & .04098 & .04100 \\
\hline 212 & 3.600 & 20 & .04586 & .04580 \\
\hline 412 & 3.427 & 5 & .05060 & .05046 \\
\hline 020 & 3.036 & 5 & .06448 & .06433 \\
\hline 1002 & 2.978 & 30 & .06701 & .06708 \\
\hline 812 & 2.931 & 40 & .06917 & .06915 \\
\hline $022^{*}$ & 2.535 & $\left.35^{1}\right)$ & .09248 & .09248 \\
\hline 1600 & 2.443 & 15 & .09957 & .09966 \\
\hline 1602 & 2.158 & 15 & .12761 & .12781 \\
\hline $1810^{*}$ & 2.045 & 35 & .14210 & .14222 \\
\hline 1620 & 1.904 & 10 & .16393 & .16399 \\
\hline 830 & 1.870 & 15 & .16993 & .16965 \\
\hline
\end{tabular}

TABLE 2

$\mathrm{X}$-ray powder data of lokkaite $(\mathrm{Cu} K \alpha, \lambda=1.5418 \AA)$

+ additional lines

The reflections marked by asterisk (*) were used to calculate the unit cell dimensions

1) The actual intensity slightly smaller due to the overlapping with tengerite reflections

\begin{tabular}{|c|c|c|c|}
\hline$\alpha$ & $\beta$ & $\gamma$ & \\
\hline 1.569 & 1.592 & 1.620 & Lokkaite (this paper) \\
\hline 1.555 & 1.57 & 1.585 & $\begin{array}{l}\text { Tengerite, Ytterby, Sweden } \\
\quad(\text { Larsen and Berman, 1934) }\end{array}$ \\
\hline- & 1.56 & - & $\begin{array}{l}\text { Tengerite, Madagascar } \\
\text { (Behier, 1960) }\end{array}$ \\
\hline 1.622 & - & 1.642 & $\begin{array}{l}\text { Tengerite, Iisaka, Japan } \\
\text { (Iimori, 1938) }\end{array}$ \\
\hline 1.611 & - & 1.636 & $\begin{array}{l}\text { Tengerite, Kazakhstan } \\
\text { (Stepanov, 1961) }\end{array}$ \\
\hline 1.620 & - & 1.642 & $\begin{array}{l}\text { Tengerite, Kazakhstan } \\
\text { (Stepanov, 1961) }\end{array}$ \\
\hline 1.64 & - & 1.66 & $\begin{array}{l}\text { Unidentified, Transvaal } \\
\text { (Verwoerd, 1963) }\end{array}$ \\
\hline
\end{tabular}

TABLE 3

Optical properties of lokkaite and related minerals 
TABLE 4

$\mathrm{X}$-ray powder patterns of tengerite and synthetic Y-carbonate

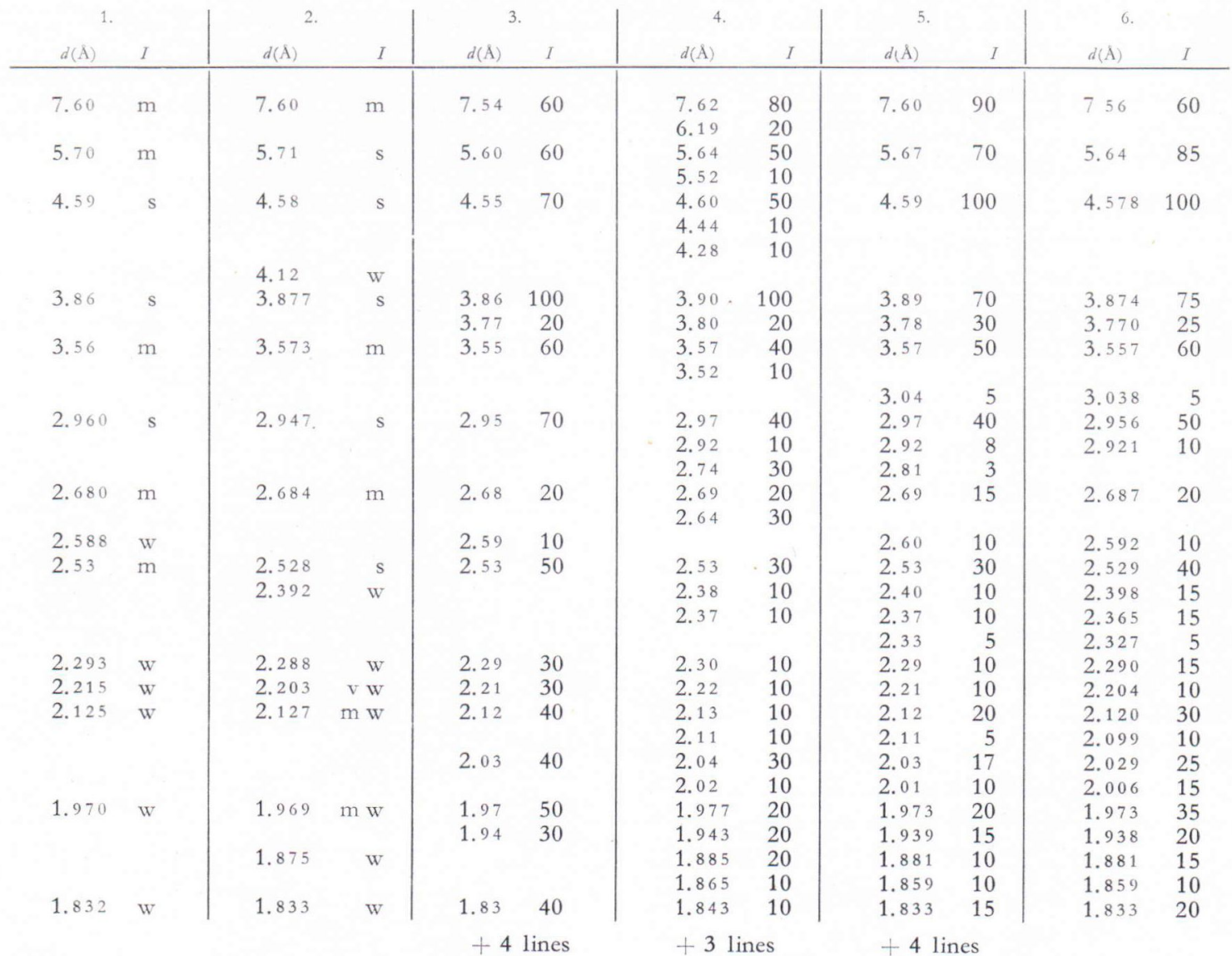

1. Tengerite*, Pyörönmaa, Finland (this paper) (Debye-Scherrer method, camera diameter $57.3 \mathrm{~mm}, \lambda=1.5418 \AA$ )

2. Tengerite, Lövböle, Finland (this paper) (Debye-Scherrer method, camera diameter $57.3 \mathrm{~mm}, \lambda=1.5418 \AA$ )

3. Tengerite, Rosås, Norway (ASTM 16-698) $(\lambda=1.93728)$

4. Tengerite, Iisaka, Japan (in Nagashima and Wakita, 1968) $(\lambda=1.5405 \AA$ )

5. Synthetic yttrium carbonate (Nagashima and Wakita, 1968) $(\lambda=1.5418 \AA)$

6. Synthetic yttrium carbonate (this paper) (Philips wide-range $X$-ray diffractometer, $\lambda=1.5418 \AA$ )

* Sample contaminated by lokkaite

All attempts to measure the density of lokkaite failed. The obtained results are too low due to adsorbed air.

\section{Discussion}

Tengerite from the type locality, Ytterby, Sweden, was poorly described (Svanberg and
Tenger, 1838) and later at least three different mineral species have been called tengerite. These »tengerites» resemble each other chemically, occur in the same way, and their indices of refraction are of the same order (Table 3 ), but they can be distinguished with certainty by $\mathrm{X}$-ray methods ( $c f$. Tables 2, 4 and 5).

The X-ray data of tengerite from Ytterby 
are lacking but the $\mathrm{X}$-ray powder pattern of tengerite from Rosås, Norway, checks with the material from Ytterby (Neumann and Bryn, 1958). The $X$-ray powder patterns of tengerites from Pyörönmaa and Lövböle*, Finland, Rosås, Norway, and Iisaka, Japan, are presented in Table 4. The comparison leaves no doubt that they represent one mineral species. It can be concluded that these data belong to tengerite.

The X-ray powder pattern of synthetic hydrous yttrium carbonate (Table 4) agrees with that of tengerite (Nagashima and Wakita, 1968). The idealized formula of the compound is $\mathrm{Y}_{2}\left(\mathrm{CO}_{3}\right)_{3} \cdot 3 \mathrm{H}_{2} \mathrm{O}$. The amount of water in the actual formula may be lower, as shown by the experiments of Nagashima and Wakita, in which case the average $\mathrm{Y}_{2} \mathrm{O}_{3}: \mathrm{CO}_{2}: \mathrm{H}_{2} \mathrm{O}=1.00: 2.90: 2.56$. The $\mathrm{X}$-ray powder pattern of synthetic yttrium carbonate, supplied to the present author by K \& K Laboratories, Inc., Plainview, N. Y. (Table 4), remains unchanged if run wet or dried at $110^{\circ} \mathrm{C}$ with the result that much of the contained water can be lost without any apparent change in the structure. According to Domingues et al. (1962) the weight loss at $110^{\circ} \mathrm{C}$ is about $7.5 \%$ and thus the actual formula is about $\mathrm{Y}_{2}\left(\mathrm{CO}_{3}\right)_{3} \cdot 1.28 \mathrm{H}_{2} \mathrm{O}$. On the basis of the work done on the synthetic material it can be concluded, as stated by Nagashima and Wakita (1968), that the structure of tengerite is the same as that of hydrous yttrium carbonate. Though all published analyzed tengerites contain calcium, this element seems to be an unessential constituent in tengerite.

Stepanov (1961) has described a RE-carbonate from Kazakhstan, USSR, as tengerite. The $\mathrm{X}$-ray powder pattern of this mineral is similar to that of the unidentified mineral of Verwoerd (1963) from Transvaal, South Africa, (Table 5) but quite different from that of tengerite (Table 4) and lokkaite (Table 2). According to Stepanov, the mineral is tetragonal with $a_{0}=8.375 \AA$ and ${ }_{0}=8.72 \AA$.

* Tengerite in Lövböle, Kemiö, SW-Finland, occurs as radial spheroids on gadolinite (Vorma et al., 1966).
TABLE 5

$\mathrm{X}$-ray powder patterns of two RE-carbonates $b k l$

011

002

121

003

013

130

222

123

231

014

033

133

240

3401

$050\}$

$\begin{array}{lr}d(\AA) & I \\ 6.0 & 60 \\ 4.30 & 50 \\ 3.426 & 60 \\ & \\ & \\ 2.895 & 80 \\ 2.734 & 40 \\ 2.638 & 100 \\ 2.450 & 30 \\ 2.283 & 30 \\ 2.234 & 40 \\ 2.102 & 40 \\ 2.012 & 60 \\ 1.956 & 20 \\ 1.871 & 100 \\ 1.672 & 40 \\ & \\ +5 & \text { lines }\end{array}$

$d(\AA)$

6.0

4.30

3.426
2.

$\begin{array}{rr}d(\AA) & I \\ 6.09 & 100 \\ 4.36 & 80 \\ 3.50 & 60 \\ 3.31 & 30 \\ 3.19 & 30 \\ 2.87 & 70 \\ 2.71 & 40 \\ 2.63 & 70 \\ 2.46 & 20 \\ 2.33 & 10 \\ 2.23 & 20 \\ 2.08 & 10 \\ 2.02 & 30 \\ 1.88 & 90 \\ 1.65 & 20 \\ +2 & \\ & \end{array}$

+2 lines
1. "Tengerite», Kazakhstan, USSR. Fe $K$, camera diameter $57.3 \mathrm{~mm}$ (Stepanov, 1961)

2. Unidentified RE-carbonate, Transvaal, South Africa. Co $K$, camera diameter $57.3 \mathrm{~mm}$ (Verwoerd, 1963)

Lokkaite was provisionally named tengerite (Vorma et al., 1966) but later proved to be a new species. It mainly occurs intimately associated with tengerite. The mutual relationship of these two minerals is not known. Their X-ray powder patterns have much in common. All of the stronger reflections of tengerite, except in $7.6 \AA$, have one or two counterparts among the reflections of lokkaite, their $d$-values varying by a few hundredths of an Ångström unit (cf. Tables 2 and 4). It is improbable that the essential difference between lokkaite and tengerite is in the degree of hydration. The distinct superstructure in lokkaite suggests the presence of an order-disorder phenomenon, either substitutional ( $\mathrm{RE}, \mathrm{Ca}$, vacancy) or rotational $\left(\mathrm{CO}_{3}^{2-}\right)$.

Acknowledgements - The author is indebted to Messrs Arvo Löfgren, Pentti Ojanperä and Jaakko Siivola for the chemical analysis of lokkaite. Sincere thanks are also due to Dr. Atso Vorma for his valuable criticism and advice during all stages of this work and to Dr. Kai Hytönen for kindly reading the manuscript. 


\section{REFERENCES}

Astm - Powder diffraction data file, sets 1-18. American Society for Testing and Materials.

Behier, JeAn (1960) Contribution a la minéralogie de Madagascar. Ann. Géol. Madagascar No. XXIX.

Domingues, Louis P., Wilfong, Roy L. and LeRoy, R. Furlong (1962) Pyrolysis of five salts of yttrium, lanthanum, and cerium. U. S. Bureau of Mines, Rept. of Invest. 6029.

Irmori, TAKeo (1938) Tengerite found in Iisaka, and its chemical composition. Sci. Papers, Inst. Chem. Res., Tokyo, 34, pp. 832-841.

INTERNATIONAL TABLES FOR X-RAY CRYSTALLOGRAPHY (1952) Vol. I Birmingham, Kynoch Press.

Larsen, Esper S. and Berman, Harry (1934) The microscopic determination of the nonopaque minerals. U. S. Geol. Survey Bull. 848.

Nagashima, Kozo and Wakita, Hisanobu (1968) On the composition of tengerite. Nippon Kagaku Zasshi, 89, 856-859.
Neumann, Heinrich and Bryn, Knut Orn (1958) $\mathrm{X}$-ray powder patterns for mineral identification IV. Carbonates. Avh. Norske Vidensk.-Akad. 1958 No. 1. Stepanov, A. V. (1961)

СТЕПАНОВ, А. В. (1961) Новые редкие минералы в щелочных гранитах fазахстана. Труды Казахского научноисследовательского института, минерального сырья, вып. 5, стр. 147-161.

Svanber G, A. F. and Tenger, C. (1838) Årsber. framst. Fysik o. Kemi af Jac. Berzelius 1838, pp.206-207. Verwoerd, W. J. (1963) Rare-earth minerals in South African carbonatites. Ann. Geol. Survey South Africa, Vol. 2, 1963, pp. 119-135.

Vorma, Atso; Ojanperä, Pentiti; Hoffrén, Väinö; Sirvola, JAAkko and Löfgren, Arvo (1966) On the rare earth minerals from the Pyörönmaa pegmatite in Kangasala, SW-Finland. C. R. Soc. Géol. Finlande 38, pp. $241-274$.

Manuscript received, April 22, 1970. 